\title{
A CASE STUDY ON GRIDHRASI WITH SHEPHALI (NIRGUNDI) GHANAVATI
}

\author{
Dr. Mugdha S. Waikar ${ }^{1}$ and Dr. B. T. Shinde ${ }^{2}$ \\ ${ }^{1}$ P.G Scholar, Department of Kayachikitsa, Ayurved College, Shevgaon, India \\ ${ }^{2}$ Guide and Principal and HOD Department of Kayachikitsa, Ayurveda college Shevgaon, India
}
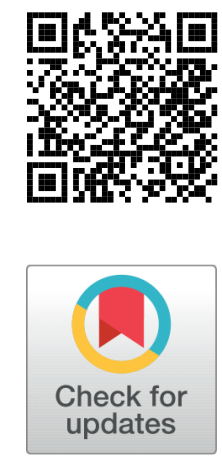

Received 29 March 2021

Accepted 16 April 2021

Published 30 April 2021

Corresponding Author

Dr. Mugdha S. Waikar, mugdhawai

kar@gmail.com

DOI $10.29121 /$

granthaalayah.v9.i4.2021.3876

Funding: This research received no specific grant from any funding agency in the public, commercial, or not-for-profit sectors.

Copyright: (C) 2021 The Author(s). This is an open access article distributed under the terms of the Creative Commons Attribution License, which permits unrestricted use, distribution, and reproduction in any medium, provided the original author and source are credited.

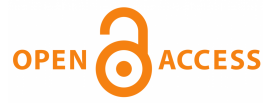

\section{ABSTRACT}

Ayurved is ancient and time tasted science. Till the date its principle remains unchange. The Ayurvedic science describes guideline for essential and harmful for long lasting healthy and happy life. Brahmanand (2017); Ravidatta and Prakashana (2017)

Several disorders of biological system are produced by improper and changing lifestyle, busy professional life, long time sitting posture in office, continuous and over exercised in factories, changing food style all are responsible for vatavyadhi and specially Gridhrasi too.

Gridhrasi is the one of the common disease. It has painful or Shoolpradhan condition which hamper the routine of life. It is occurs about three times as frequency in male as in the female as in the female sex.

Gridhrasi is one of the Nanatmaj vyadhi and vata is is the main dosha in the Samprapti. It is the closely resemble with Sciatica which is characterised by low back pain and radiates towards leg mostly unilateral.

The case study being presented of 42 years old female patient suffering from Vataj Gridhrasi with cardinal signs and symptoms of Gridhrasi are Ruk,toda,Stambh, and radiating pain in the leg in order of Sphik, Kati,Uru, Janu, Pad.Here Shaman chikitsa done with Shephali(Nirgundi) Ghanavati · "pandit Kashiram Vaidya virachit Gudharth Dipikabhyam commentary, Sharangdhar Samhita, madhyam khand" (n.d.); Sharma and Priyavat (n.d.).

Keywords: Gridhrsi, Vata, Pain, Shaman Chikitsa, Sciatica

\section{INTRODUCTION}

Gridhasi word derived from Gridhras by adding Din Prataya. Kanta (1988) It is describe under 80 types of Vatavyadhi. Dr, Brahmanand, and Varanasi (2008)Gridhrasi is characterised by Sphikpurva ruk in Kati, Uru, Janu, Jangha, Pad and associated with Toda, Stambh, Muhuspandan. Also Tandra, Gaurav, Aruchi present in Kaphavataj Gridhrsi.In this disease patient gait becomes altered as 
patients leg become tense and slightly curve due to the pain resembling walk to like vulture Dr, Brahmananda, and Varanasi (2008).

Here patient get treated with Shaman Chikitsa with Shephali (Nirgundi) Ghanavati. Nirgundi mentioned in Sharangdhar Samhita as a Shephalipatra Kwath in cure for

Gridhrasi where Shephali is synonym for Nirgundi. Also Bhavprakash mentioned Shephali for Nirgundys synonym.

Gridhrasi can be correlated with sciatica. Sciatica characterised by low back pain spreads through the hip to the back of thigh and down towards leg. This basically arises due to compression or inflammation of sciatic nerve. Das (n.d.)

According to Ayurveda Gridhrasi mentioned as Kricchrasadhya which is very difficult to cure Dr and Brahmanand (2017).

\section{CASE REPORT}

A 43 years old male patient comes to OPD of Kayachikitsa department of Santa Ekanath Ayurvedic Hospital, Shevgaon. Patient was farmer by occupation. Patient came with following chief complaints:

On Dakshin pada - Chief Complaints:

1. Ruk (Pain)

2. Toda (Pricking sensation)

3. Stambha (Stiffness)

4. Sanchar vedana (Radiating Pain)in order Sphik, Uru, Kati, Janu, Pad.

5. Chankraman and Aasan kashtata (pain while walking and sitting) - $\quad$ starts before 4 to 5 weeks.

\section{HISTORY OF CASE STUDY}

Patient had taken allopathic treatment before came to our hospital as per need for his pain and he was not satisfied by it by having repeat episodes. Patient did not have history of any other major illness.

\subsection{FAMILY HISTORY}

No any major illness

\subsection{ON EXAMINATION}

General condition - Moderate, Afebrile. No pallor/Icterus was present. 


\begin{tabular}{ll}
\hline Table 1 & \\
\hline Nadi - 78/min. & Shabda - Avishesha \\
Mala - Samyak & Sparsha - Ruksha \\
Mutra - Samyaka & Druka - Avishesha \\
Jlvha - Niram & Akruti - Madhyam \\
Weight - 65kg & Blood pressure - 124/86 mm of hg \\
\hline
\end{tabular}

\subsection{ASTHAVIDH PARIKSHA}

\section{NIDAN PANCHAK}

\subsection{HETU Joshi and Prakashana (2014a)}

Yanayan, aticheshta ,Katu- Ruksha anna

\subsection{SAMPRAPTI Das (n.d.); Joshi and Prakashana (2014b)}

Samprapti Ghatak -

$$
\begin{aligned}
& \text { Doshas - Vata dosha prakop } \\
& \text { Dushya - Majja, Asthi } \\
& \text { Agni - Mandagni. }
\end{aligned}
$$

Strotodushti - Sanga,Siragranthi. .

Vydhiswabhav - aashukari/Chirkari.

Vyaktasthana - Katipradesh, Uru, Janu, Pad

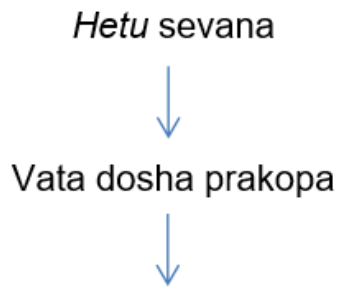

Strotas sthanvaigunya, Rikta Strotas vayupuran

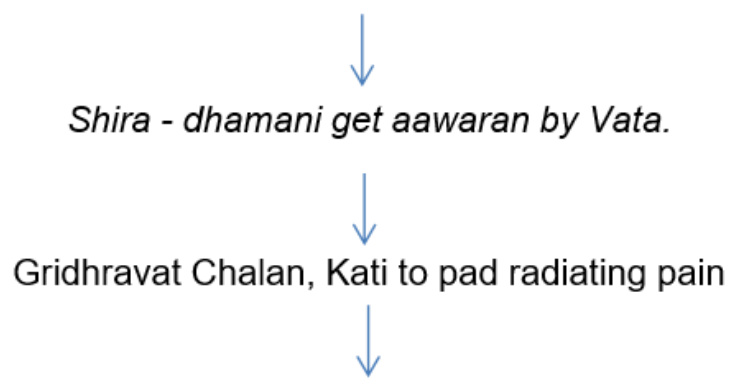

Gridhrasi

\subsection{Poorvarupa}

Pain and stiffness at Lumbar region and low back region. 


\subsection{ROOPA Joshi and Prakashana (2014c)}

Pain in Lumbar region and radiating towards Shik, Kati, Uru, Janu, Pad.

\subsection{UPASHAYA}

Aushadh sevana

\subsection{ANUPSHAYA}

Nidansevana

\section{MATERIALS AND METHOD}

Centre of study- Santa Ekanath Maharaj

Hospital, Shevgoan. Material- Shephali Ghanavati. (250 gm)

Method - Case study

\section{CHIKITSA}

Shaman chikitsa with Shephali (Nirgundi) Ghanavati showed excellent result in this case.

Shephali (Nirgundi) Ghanavati: 500 gm BD(1 gm/Day) with Sukhoshna jala after food.

For 30 days by taking follow up after 7,15 and $30^{\text {th }}$ day.

\section{ASSESSMENT CRITERIA}

\subsection{SUBJECTIVE PARAMETERS}

\subsection{OBJECTIVE PARAMETERS}

1. SLRT

2. Walking time

\section{OBSERVATION}

\subsection{SUBJECTIVE CRITERIAb Table 3}

\subsection{OBJECTIVE PARAMETERSTable 4}

\section{RESULT AND DISCUSION}

In this case study patient get treated by Shaman Chikitsa that is internal medicine with Shephali (Nirgundi) Ghanavati with Sukhoshna jala for 30 days. After the treatment patient shows great result in his sigh and Symptoms about Gridhrasi. He started walking and sitting comfortably. Nirgundi is Vataghna and Shothaghna dravya. Is great in Vaataj vikar with its Ushna Vipaka and Katu Tikta Rasa. 


\begin{tabular}{|c|c|c|c|}
\hline \multicolumn{4}{|c|}{ Table 2} \\
\hline $\begin{array}{l}\text { Sr. } \\
\text { No. }\end{array}$ & Symptoms & Grade & Description \\
\hline \multirow[t]{6}{*}{1.} & Ruk ( Pain ) & 0. & No pain \\
\hline & & 1. & Slight pain only on hard work \\
\hline & & 2. & Pain on movement but without disturbing \\
\hline & & & routine work \\
\hline & & 3. & $\begin{array}{l}\text { Pain on movement disturbing routine } \\
\text { work }\end{array}$ \\
\hline & & 4. & $\begin{array}{l}\text { Severe pain compelling patients to lie on } \\
\text { bed }\end{array}$ \\
\hline \multirow[t]{5}{*}{2.} & $\begin{array}{l}\text { Toda (Pricking sensa- } \\
\text { tion) }\end{array}$ & 0. & No pricking sensation \\
\hline & & 1. & Occasionally pricking sensation \\
\hline & & 2. & Mild pricking sensation, once in a day \\
\hline & & 3. & $\begin{array}{l}\text { Moderate pricking sensation, frequently } \\
\text { in a } \\
\text { day }\end{array}$ \\
\hline & & 4. & Severe and persistence pricking sensation \\
\hline \multirow[t]{5}{*}{3.} & Stambha (Stiffness) & 0. & No stiffness \\
\hline & & 1. & Sometimes for $5-10 \mathrm{~min}$. \\
\hline & & 2. & Daily for $10-30 \mathrm{~min}$. \\
\hline & & 3. & Daily for $30-60 \mathrm{~min}$. \\
\hline & & 4. & Daily more than 1 hour. \\
\hline \multirow[t]{4}{*}{4.} & $\begin{array}{l}\text { Chankraman and } \\
\text { Aasan kashata (Diffi- } \\
\text { culty in } \\
\text { walking and sitting) }\end{array}$ & 0. & No pain \\
\hline & & 1. & $\begin{array}{l}\text { Mild pain }+ \text { No difficulty in sitting and } \\
\text { walking. }\end{array}$ \\
\hline & & 2. & Slight pain in walking and sitting \\
\hline & & 3. & Much difficulty in walking and sitting. \\
\hline
\end{tabular}

Table 3

\begin{tabular}{ccc}
\hline Sign and symptom & Before treatment & After treatment \\
Ruk & 3 & 0 \\
Tod & 3 & 1 \\
Stambha & 2 & 0 \\
\hline Chankraman and aasan kashtata & 3 & 0 \\
\hline
\end{tabular}

Table 4

\begin{tabular}{ccc}
\hline & Before treatment & After treatment \\
\hline SLRT & Positive at $35^{\circ}$ (right leg) & Negative at $75^{\circ}$ (right leg) \\
\hline Walking time & 100 meters in 10 seconds. & 100 meters in 5 seconds. \\
\hline
\end{tabular}




\section{CONCLUSION}

Above treatment helps to relieve symptoms of disease and also an attempt to provide safe and effective treatment to the patient. Treatment was easily administrated to patient. And no side effects were noticed.

\section{REFERENCES}

Brahmanand, R. T. (2017). Ashtang hriday Samhita , purvardha, sutrasthana, chapter 1 st.

Das, S. (n.d.). A manual of clinical surgery - 7th edition, Examination of peripheral nerve lission, Page no. 97,Examination of spinal abnormalities., 225-225.

Dr, T., \& Brahmanand. (2017). Ashtang hriday Samhita , purvardha , Nidansthana , Atosargrahanidoshanidanam., 30, 497-497.

Dr, T., Brahmanand, \& Varanasi. (2008). Editor Charak Samhita of Agnivesha, Sutrasthan ,Maharaga adhyay.

Dr, T., Brahmananda, \& Varanasi. (2008). Editor Charak Samhita of Agnivesha , Chikitsasthana , vatavyadhi chikitsa adhyaya 28., 53, 590-590.

Joshi, V., \& Prakashana, Y. V. (2014a). Edited by Ayurveda dipika Vyakhya , and yashavant commentary , Chikitsasthana, Charak Samhita., 28, 620-620.

Joshi, V., \& Prakashana, Y. V. (2014b). Edited by Ayurveda dipika Vyakhya , and yashavant commentary , Chikitsasthana , Charak Samhita., 620-620.

Joshi, V., \& Prakashana, Y. V. (2014c). Edited by Ayurveda dipika Vyakhya , and yashavant commentary, Chikitsasthana, Charak Samhita., 28.

Kanta, R. R. (1988). Edited Shabda Kalpadruma 2 nd volume. In Nag publication (pp. 345$345)$.

pandit Kashiram Vaidya virachit Gudharth Dipikabhyam commentary, Sharangdhar Samhita , madhyam khand. (n.d.)., 155-155.

Ravidatta, T., \& Prakashana, C. S. (2017). Edited with Vaidyamanorama Hindi Commentary along with special Delibration etc. Sutrasthana , 1 st chapter, 1, 41-41.

Sharma, A., \& Priyavat. (n.d.). Reprinted 2011, dravyaguna vidyana, 2. 